\title{
BONA FIDES (POŠTENJE POSJEDA) KOD ZASTARE (PRAESCRIPTIO ACQUISITIVA) I DOSJELOSTI (USUCAPIO) - PRILOG RASPRAVI O SUODNOSU KANONSKOG I HRVATSKOG PRAVA
}

Doc. dr. sc. Henrik-Riko Held*

UDK: $347.251(497.5)$

$347.439(497.5)$

$348: 347.2(497.5)$

DOI: $10.3935 /$ zpfz.70.6.02

Izvorni znanstveni rad

Primljeno: prosinac 2020.

U radu se analiziraju bona fides i poštenje posjeda kao pretpostavke kanonskopravne zastare (praescriptio acquisitiva) te dosjelosti hrvatskog prava $u$ njihovu suodnosu. Naime, djelovanjem ugovora izmedu Svete Stolice i RH o pravnim pitanjima u određenim slučajevima vezanima uz crkvene pravne osobe $i$ njihovu imovinu primjenjuju se odredbe kanonskog prava te je cilj rada utvrditi na koji se način to odnosi i na ovu pretpostavku. Nakon opće analize kanonskopravne zastare te pretpostavke dobre vjere kod dosjelosti u rimskoj pravnoj tradiciji zasebno se obrađuje kanonskopravna bona fides i njezine specifičnosti koje ju čine strožim standardom od poštenja posjeda hrvatskog prava. Naposljetku se zaključuje kako se kanonskopravna bona fides primjenjuje kad god crkvene pravne osobe stječu imovinu dosjelošću, a po svemu sudeći i kad se istim načinom stječe njihova imovina.

Ključne riječi: bona fides, poštenje posjeda, praescriptio, dosjelost, kanonsko pravo

* Dr. sc. Henrik-Riko Held, docent Pravnog fakulteta Sveučilišta u Zagrebu, Trg Republike Hrvatske 14, 10000 Zagreb; hheld@pravo.hr;

ORCID ID: orcid.org/0000-0002-6217-2655 


\section{UVOD**}

Kanonsko pravo u najopćenitijem bi se smislu moglo definirati kao pravo Katoličke Crkve (dalje u tekstu: KC), i to kao pravni poredak koji usmjerava i koordinira vjernike u postizanju njima zajedničkih ciljeva. ${ }^{1}$ Pritom su njegov nastanak, duga povijest razvoja te posljedično i suvremeno uređenje snažno povezani s rimskim pravom i rimskom pravnom tradicijom. ${ }^{2} \mathrm{U}$ tom smislu kanonsko pravo ima zajedničke temelje s mnogim europskim pa i svjetskim pravnim poredcima. ${ }^{3}$ Osim toga, ono je samostalno i po vlastitim posebnostima

** Rad je nastao i zahvaljujući višegodišnjim potporama Sveučilišta u Zagrebu istraŽivanjima na projektu Rimsko-kanonska pravna tradicija i europeizacija hrvatskog prava (2015. - 2019.), na kojem je autor bio istraživač.

1 Cf. Marthaler, B. L. (ur.), New Catholic Encyclopedia, vol. 3, Gale, Detroit, 2003., str. 37 (unos Canon Law, History of); Arroba Conde, M. J., Introduzione al diritto canonico, Mondadori, Milano, 2019., str. 2; Gaudemet, J., Il diritto canonico, Giappichelli, Torino, 1991., str. 3; Škalabrin, N., Uvod u kanonsko pravo, Katolički bogoslovni fakultet Sveučilišta u Zagrebu, Teologija u Đakovu, Sveučilište Josipa Jurja Strossmayera u Osijeku, Pravni fakultet, Đakovo, 1994., str. 5. Više o važnosti i konceptualnom položaju kanonskog prava unutar općeg nauka KC-a u: Škalabrin, op. cit. u ovoj bilješci, str. 60 sqq.; Örsy, L. M., Theology and Canon Law, u: Beal, J. P.; Coriden, J. A.; Green, T. J. (ur.), New Commentary on the Code of Canon Law, Paulist, New York, 2000., str. 1 - 10 .

2 Za pregled povijesti kanonskog prava vidi Musselli, L., Storia del diritto canonico, Giappichelli, Torino, 2007.; Marthaler, op. cit. u bilj. 1, str. 37 sqq., s iscrpnim uputama na daljnju literaturu; $c f$. i Škalabrin, op. cit. u bilj. 1, str. 87 sqq. Posebna važnost rimskog prava za kanonsko pravo očituje se i u poznatoj sentenciji Ecclesia vivit lege romana, koja potječe iz pravne zbirke Lex Ripuaria s početka 7. st. (više o tomu u: Fürst, C. G., Ecclesia vivit lege romana?, Zeitschrift der Savigny-Stiftung für Rechtsgeschichte, Kanonistische Abteilung, vol. 61, br. 1, 1975., str. 17 - 36). Povijesno su postojala razdoblja više i manje snažnog utjecaja rimskog prava, što je dijelom bilo odraz ponekad turbulentnih odnosa između Crkve i svjetovnih vlasti. No postojale su i unutarcrkvene kontroverze o tomu koliko je potrebno ili poželjno dopustiti snažniji utjecaj ili infiltraciju svjetovnog pravnog elementa (povijesno utjelovljenog u recipiranom rimskom pravu) u Crkvu, ne samo zbog opasnosti snažnijeg utjecaja svjetovnih vlasti nego i zbog mogućeg ugrožavanja specifičnog poslanja Crkve (iscrpnije o tomu u: Robleda, O., El derecho romano en la Iglesia, u: Navarette, U. (ur.), Ius populi Dei. Miscellanea in honorem Raymundi Bidagor, vol. I, Universitá Gregoriana Editrice, Roma, 1971., str. I - 52; cf. De Paolis, V., I beni temporali della Chiesa, EDB, Bologna, 2011., str. 71).

3 Općenito o utjecaju rimskog prava na europske pravne poretke u: Stein, P., Rimsko pravo i Europa, Golden marketing - Tehnička knjiga, Zagreb, 2007. 
znatno utjecalo na oblikovanje suvremenih pravnih sustava. ${ }^{4}$ Hrvatsko pravo, čija je utemeljenost u rimskoj pravnoj tradiciji sasvim nedvojbena, nije iznimka od navedenih fenomena. ${ }^{5}$ Suvremeni hrvatski pozitivnopravni okvir otvara i određene nove perspektive i potencijalne praktične i teorijske konceptualne izazove glede odnosa između hrvatskog prava i kanonskog pravnog poretka. U tom kontekstu ključni su ugovori između Svete Stolice i RH u četirima različitim područjima. ${ }^{6} \mathrm{~S}$ obzirom na to da je riječ o međunarodnim ugovorima, njihovo uređenje određenih pitanja koja se odnose na pravni položaj KC-a i njezinih pravnih osoba dobilo je, djelovanjem čl. 134. Ustava $\mathrm{RH}^{7}$, nadzakonsku

4 Od bogate literature o tomu posebno se može istaknuti serija Der Einfluss der Kanonistik auf die europäische Rechtskultur, od čega je u predmetnom kontekstu možda najrelevantnije izdanje Condorelli, O.; Roumy, F.; Schmoeckel, M. (ur.), Der Einfluss der Kanonistik auf die europäische Rechtskultur, Band I: Zivil- und Zivilprozessrecht, Böhlau, Köln, 2009.

5 Cf. u tom smislu posebno Petrak, M., Kanonsko pravo i hrvatski pravni sustav (I). Pravni izvori i pravna načela, Zbornik Pravnog fakulteta u Zagrebu, vol. 70, br. 2-3, 2020., str. 251 - 286; Petrak, M., Kanonsko pravo i hrvatski pravni sustav (II). Codex Iuris Canonici i suvremeno hrvatsko pravo, Zbornik Pravnog fakulteta u Zagrebu, vol. 70, br. 5, 2020., str. 675 - 708 te u monografskom obliku Petrak, M.; Staničić, F., Katolička Crkva, vjerske zajednice i hrvatski pravni sustav, Novi Informator, Zagreb, 2020., str. 57 sqq.

6 Ugovor između Svete Stolice i Republike Hrvatske o pravnim pitanjima (za tekst vidi i Odluku o proglašenju Zakona o potvrđivanju tog ugovora, Narodne novine, Međunarodni ugovori, br. 3/1997), Ugovor između Svete Stolice i Republike Hrvatske o suradnji na području odgoja i kulture (za tekst vidi i Odluku o proglašenju Zakona o potvrđivanju tog ugovora, Narodne novine, Međunarodni ugovori, br. 2/1997) i Ugovor između Svete Stolice i Republike Hrvatske o dušobrižništvu katoličkih vjernika, pripadnika oružanih snaga i redarstvenih službi Republike Hrvatske (za tekst vidi i Odluku o proglašenju Zakona o potvrđivanju tog ugovora, Narodne novine, Međunarodni ugovori, br. 2/1997) stupili su na snagu 9. travnja 1997. izmjenom ratifikacijskih isprava između visokih ugovornih stranaka. Ugovor između Svete Stolice i Republike Hrvatske o gospodarskim pitanjima (za tekst vidi i Odluku o proglašenju Zakon o potvrđivanju tog ugovora, Narodne novine, Međunarodni ugovori, br. 18/1998) stupio je na snagu 14. prosinca $1998 .$, također izmjenom ratifikacijskih isprava među visokim ugovornim strankama. Za povijesni pregled nastanka tih ugovora i ratifikacijski postupak vidi Eterović, N.; Bozanić, J., Ugovori između Svete Stolice i Republike Hrvatske, Glas Koncila, Zagreb, 2001., str. 15 - 22. U istom djelu mogu se naći predmetni ugovori usporedno u objema službenim varijantama na talijanskom i hrvatskom jeziku uz komentar njihovih odredbi.

7 Narodne novine, br. 56/1990, 135/1997, 08/1998, 113/2000, 124/2000, 28/2001, 41/2001, 55/2001, 76/2010, 85/2010, 5/2014. Čl. 134. propisuje: Međunarodni ugovori koji su sklopljeni i potvrđeni u skladu s Ustavom i objavljeni, a koji su na snazi, čine dio unutarnjeg pravnog poretka Republike Hrvatske, a po pravnoj su snazi iznad zakona. 
pravnu snagu. Zbog toga KC i njezine pravne osobe u Hrvatskoj u određenim pitanjima imaju poseban pravni položaj te se javlja mogućnost izravne primjene kanonskog prava u određenim odnosima i u svjetovnom pravnom kontekstu, što je u nedavnoj literaturi sustavno analizirano. ${ }^{8}$ Ovdje se može istaknuti kako se, zahvaljujući Ugovoru između Svete Stolice i Republike Hrvatske o pravnim pitanjima (dalje u tekstu: Ugovor o pravnim pitanjima), posebnost tog položaja očitovala i u kontekstu imovinskopravnog položaja crkvenih pravnih osoba. ${ }^{9}$ Naime, u tom području s jedne strane KC kanonskim propisima u određenim pitanjima preuzima svjetovno pravo zemlje u kojoj djeluju njezine pravne osobe (takozvana kanonizacija svjetovnog prava). ${ }^{10}$ No s druge strane Ugovor o pravnim pitanjima otvara prostor primjeni određenih aspekata kanonskog imovinskog prava koje na taj način može izravno stvarati imovinskopravne učinke u pravnom poretku RH. Navedeni se proces u literaturi nazvao i "civilifikacijom" kanonskog prava, uz izraz ius canonicum in iure civili. ${ }^{11}$

Ovaj rad koncipiran je kao prilog raspravama koje analiziraju suodnos kanonskog i suvremenog hrvatskog prava, i to u kontekstu rimske pravne tradicije kao zajedničkog izvorišta i zapravo sasvim aktualnog terminološkog i konceptualnog konteksta obaju sustava. Usredotočen je na dobru vjeru (bona fides), odnosno poštenje posjeda kao pretpostavku kanonskopravne zastare (praescriptio acquisitiva) s jedne te dosjelosti (usucapio) suvremenog hrvatskog prava s druge strane. Naime, bona fides je još u rimskom pravu bila pretpostavka stjecanja vlasništva dosjelošću (usucapio, praescriptio), što je tijekom recepcije rimskog prava bilo prihvaćeno i

8 Petrak, op. cit. u bilj. 5 (Codex) te u monografskom obliku Petrak; Staničić, op. cit. u bilj. 5, posebno str. 57 sqq.

9 Cf. o tomu Brkan, J., Crkvena vremenita dobra, Crkva u svijetu, vol. 39, br. 1, 2004., str. 62 - 94, posebno str. 71 sq., 80 sqq.; Brkan, J., Stjecanje vremenitih dobara, Bogoslovska smotra, vol. 74, br. 1, 2004., str. 201 - 231, posebno str. 202 sq., 221; Brkan, J., Zastara u kanonskom i građanskom pravu, Crkva u svijetu, vol. 38, br. 3, 2003., str. 373 - 390, posebno str. 383; Škalabrin, N., Vremenita crkvena dobra, Bogoslovska smotra, vol. 74, br. 1, 2004., str. 181 - 199, posebno str. 194; Škalabrin, N., Ugovori i napose otuđenje, Bogoslovska smotra, vol. 76, br. 1, 2006., str. 173 - 199, posebno str. 194; Petrak, op. cit. u bilj. 5 (Codex), str. 692 sqq., 697 sqq.

10 Više o kanonizaciji općenito u monografskom obliku Miñambres, J., La remisión de la ley canónica al derecho civil, Ateneo romano della Santa Croce, Roma, 1992., posebno str. 67 sqq. i 119 sqq. te Chiappeta, L., Il Codice di diritto canonico. Commento giuridico-pastorale, vol. 1, EDB, Bologna, 2011., str. 45 sq.; De Paolis, op. cit. u bilj. 2 , str. 72 sqq. Od kanonizacije treba razlikovati puku preporuku ili upućivanje na poštovanje svjetovnog prava u određenim slučajevima ( $c f$. De Paolis, op. cit. u bilj. 2 , str. 74; Škalabrin, N., Vremenita crkvena dobra, Sveučilište Josipa Jurja Strossmayera u Osijeku, Katolički bogoslovni fakultet u Đakovu, Đakovo, 2008., str. 31 sq.).

11 Cf. Petrak, op. cit. u bilj. 5 (Izvori), str. 256; Petrak, op. cit. u bilj. 5 (Codex), str. 678. 
razrađeno podjednako u civilističkoj i kanonističkoj doktrini i praksi. Uz to je postojao i uzajamni utjecaj između dvaju sustava, no naposljetku su se razvila autonomna uređenja s vlastitim posebnostima. Kako je već napomenuto ranije, suvremeni hrvatski pozitivnopravni okvir općenito je otvorio prostor primjeni određenih kanonskopravnih instituta u svjetovnom pravnom okruženju. Cilj predmetne analize jest utvrditi odnosi li se to i na problematiku dobre vjere (bona fides) te, u slučaju potvrdnog odgovora, razjasniti na koje se situacije primjenjuje te koje bi bile praktične i konceptualne posljedice. U literaturi je već analizirana problematika rokova kod zastare (praescriptio acquisitiva) i dosjelosti, odnosno pitanje koji se rokovi trebaju primijeniti u određenim situacijama vezanima uz crkvene pravne osobe i njihovu imovinu na temelju suvremenog hrvatskog pozitivnopravnog okvira. ${ }^{12}$ Ovim radom, nadamo se, doprinijeli bismo navedenoj tematici te na specifičnom i konkretnom primjeru razjasnili praktične pravne posljedice, ali i šire konceptualne implikacije. Time bi se u jednom posebnom aspektu i specifičnom hrvatskom pozitivnopravnom kontekstu analizirao nastavak aktivne interakcije kanonskog i svjetovnog prava koji je postojao u povijesnoj razvojnoj perspektivi, a koji u kontekstu rimskog prava i rimske pravne tradicije kao zajedničkog izvorišta obaju pravnih sustava postoji i dalje.

\section{KANONSKOPRAVNI INSTITUT ZASTARE (PRAESCRIPTIO) U KONTEKSTU RIMSKE PRAVNE TRADICIJE}

Unutar kanonskopravnog uređenja određenih imovinskih pitanja ili, koristeći se kanonskim izrazom, tematike vezane uz vremenita crkvena dobra (de bonis Ecclesiae temporalibus) $)^{13}$ nalazi se i tzv. zastara, odnosno praescriptio. Tako Codex Iuris Canonici, odnosno Zakonik kanonskog prava, iz 1983. (dalje u tekstu: CIC $)^{14}$, kao temeljni izvor prava za latinsku Crkvu, u kann. 197. - 199. na načelnoj razini uređuje zastaru kao način stjecanja ili gubitka subjektivnoga prava

12 Petrak, op. cit. u bilj. 5 (Codex), str. 697 sqq.

13 Više o povijesti uređenja imovinskopravnih pitanja u Crkvi, kao i uzrocima i svrhama zašto se ta pitanja uopće uređuju kanonskim pravom, vidi u: De Paolis, op. cit. u bilj. 2, str. 9 sqq.; Pranjić, P., Vremenita dobra i vremenita dobra u Crkvi, Katolički bogoslovni fakultet, Sarajevo, Glas Koncila, Zagreb, 2013., str. 15 sqq.; Škalabrin, op. cit. u bilj. 10, str. 13 sqq.

14 Za usporedni tekst na latinskom i hrvatskom vidi Codex Iuris Canonici fontium annotatione auctus (Zakonik kanonskog prava s izvorima), Glas Koncila, Zagreb, 1996. 
i oslobađanja od obveza, što je dopunjeno u kann. 1268. - 1270..$^{15,16} \mathrm{U}$ osnovi je preuzeto uređenje kakvo je sadržavao prethodni Codex Iuris Canonici iz 1917. godine $^{17}$ u kann. 1508. - 1512. Uz to, Codex Canonum Ecclesiarum Orientalium, odnosno Zakonik kanona istočnih Crkava iz 1990. (dalje u tekstu: CCEO) ${ }^{18}$, temeljni izvor prava za istočne katoličke crkve, sadržava odgovarajuće odredbe u kann. 1540. - 1542. te 1017. - 1019..$^{19,20} \mathrm{Na}$ temelju spomenute definicije pojma zastare (praescriptio) vidljivo je terminološko nesuglasje između kanonskog prava i suvremenog hrvatskog prava. Naime, u kanonskom pravu pod tim se pojmom s jedne strane podrazumijeva način stjecanja vlasništva koji se u hrvatskom pravu naziva dosjelost i koji uređuje Zakon o vlasništvu i drugim stvarnim pravima (dalje u tekstu: ZV $)^{21}$, a u tom je smislu taj pojam i predmet ove analize. No s

15 Uz navedeno CIC na više mjesta spominje zastaru (praescriptio) vezano uz određene specifične aspekte koji ovdje nisu predmet analize (iscrpan popis kanona donosi Brkan, op. cit. u bilj. 9 (Zastara), str. 375).

16 Za analizu navedenih kanona vidi Chiappeta, op. cit. u bilj. 10, str. 262 sqq.; Chiappeta, L., Il Codice di diritto canonico. Commento giuridico-pastorale, vol. 2, EDB, Bologna, 2011., str. 546 sqq.; Beal; Coriden; Green, op. cit. u bilj. 1, str. 230 sqq., 1470 sqq. te općenito iscrpno o zastari (praescriptio) u kanonskom pravu u: De Paolis, op. cit. u bilj. 2, str. 161 sqq.; Brkan, op. cit. u bilj. 9 (Zastara); Škalabrin, op. cit. u bilj. 10, str. 47 sqq.; Škalabrin, N., Stjecanje dobara, Bogoslovska smotra, vol. 75, br. 1, 2004., str. 233 - 262, str. 244 sqq.

17 Za usporedni tekst na latinskom i hrvatskom vidi Codex Iuris Canonici fontium annotatione auctus MDCCCCXVII (Kodeks kanonskog prava s izvorima 1917.), Glas Koncila, Zagreb, 2007.

18 Za usporedni tekst na latinskom i hrvatskom vidi Codex Canonum Ecclesiarum Orientalium fontium annotatione auctus (Zakonik kanona istočnih Crkava s izvorima), Glas Koncila, Zagreb, 1996.

19 CCEO također zastaru (praescriptio) spominje i na nekim drugim mjestima (iscrpan popis kanona u: Brkan, op. cit. u bilj. 9 (Zastara), str. 375).

20 Uzevši u obzir okolnost kako u Hrvatskoj (a i u svijetu) većina katoličkih vjernika pripada latinskoj Crkvi (cf. u tom smislu i Petrak, op. cit. u bilj. 5 (Codex), str. 680; Petrak; Staničić, op. cit. u bilj. 5, str. 77), u radu su u prvom redu navođeni kanoni CIC-a zajedno s pripadajućom literaturom. Međutim, nije zanemarena ni činjenica kako u hrvatskom kontekstu, s obzirom na grkokatoličku Križevačku eparhiju, pravnu relevantnost ima i kodifikacija za istočne crkve te se stoga uz kanone CIC-a, kad je to prikladno, navode i odgovarajući kanoni CCEO-a.

21 Narodne novine, br. 91/1996, 68/1998, 137/1999, 22/2000, 73/2000, 129/2000, 114/2001, 79/2006, 141/2006, 146/2008, 38/2009, 153/2009, 143/2012, 152/2014, i to u čl. 159. - 160. Više o dosjelosti u: Klarić, P.; Vedriš, M., Gradansko pravo, Narodne novine, Zagreb, 2006., str. 275 sqq.; Gavella, N. et al., Stvarno pravo, sv. 1, Narodne novine, Zagreb, 2007., str. 556 sqq. U domaćoj literaturi, poglavito stručnoj, posebnu pažnju zauzimala je problematika dosjelosti u kontekstu određenih 
druge strane kanonska zastara ima i drugo značenje, sadržajno podudarno sa zastarom u hrvatskom pravu koja označava gubitak zahtjeva zbog nevršenja subjektivnog prava kroz određeno vrijeme. ${ }^{22}$ Zbog toga kanonskopravna doktrina razlikuje tri različite vrste zastare, i to praescriptio acquisitiva, kojom se neko pravo stječe, praescriptio extinctiva, kojom se ono gubi te praescriptio liberativa, kojom dolazi do oslobođenja od obveze. ${ }^{23}$

Usprkos navedenoj terminološkoj neusklađenosti nema dvojbe kako i suvremeni hrvatski koncept dosjelosti i kanonskopravna zastara potječu iz rimskog prava i rimske pravne tradicije. ${ }^{24}$ Uostalom, zapravo se i u suvremenoj hrvatskoj građanskopravnoj doktrini zastara teoretski koncipira kao svojevrsna suprotnost dosjelosti ${ }^{25}$, samo što se to ne odražava u terminologiji kao u kontekstu kanonskog prava. Uz to, kanonsko pravo općenito kod uređenja zastare (praescriptio) upućuje na načelnu primjenu svjetovnog prava. ${ }^{26} \mathrm{Zbog}$ toga se praktične

specifičnih objekata kao što su nekretnine u (bivšem) društvenom vlasništvu ili poljoprivredna zemljišta ( $c f$. u tom smislu, primjerice, Žuvela, M., Dosjelost i društveno vlasništvo, Informator, vol. 56, br. 5707, 2008., str. 1 - 3; Kontrec, D., Stjecanje prava vlasništva dosjelošću na nekretninama u društvenom vlasništvu u svjetlu nove prakse Europskog suda za ljudska prava, Zbornik Pravnog fakulteta Sveučilišta u Rijeci, vol. 38, br. 1, 2017., str. 573 - 594; Simonetti, P., Stjecanje prava vlasništva primjenom ustanova dosjelosti i uzurpacije na nekretninama koje su bile u društvenom vlasništvu, Zbornik Pravnog fakulteta Sveučilišta u Rijeci, vol. 29, br. 1, 2008., str. 27 - 70; Peček, R., Dosjelost u korist nekadašnjeg društvenog vlasništva na nekretnini u privatnom vlasništvu, Informator, vol. 61, br. 6184, str. 5 - 6; Milaković, G., Dosjelost kao način stjecanja prava vlasništva Republike Hrvatske na poljoprivrednom zemljištu, 1. dio, Informator, vol. 61, br. 6141, str. 5 - 6; Milaković, G., Dosjelost kao način stjecanja prava vlasništva Republike Hrvatske na poljoprivrednom zemljištu, 2. dio, Informator, vol. 61, br. 6142, str. 12 - 13).

Zastara je na općoj razini u hrvatskom pravu uređena u Zakonu o obveznim odnosima, Narodne novine, br. 35/2005, 41/2008, 125/2011, 78/2015, 29/2018, i to u čl. 214. - 246. (cf. Klarić; Vedriš, op. cit. u bilj. 21, str. 182 sqq.).

23 Cf. Chiappeta, op. cit. u bilj. 10, str. 262; Beal; Coriden; Green, op. cit. u bilj. 1, str. 230; De Paolis, op. cit. u bilj. 2, str. 161 sq.; Škalabrin, op. cit. u bilj. 10, str. 47; Brkan, op. cit. u bilj. 9 (Zastara), str. 376 sq.

24 Za hrvatsko pravo $c f$., primjerice, Petrak, M., Traditio iuridica: Usucapio, Informator, vol. 58, br. 5863, str. 3, a za kanonsko pravo Beal; Coriden; Green, op. cit. u bilj. 1, str. 230; Chiappeta, op. cit. u bilj. 10, str. 262.

Klarić; Vedriš, op. cit. u bilj. 21, str. 182.

Kan. 197. CIC-a ( $c f$. kan. 1540. CCEO-a). Ovo je jedan od dvaju temeljnih primjera kanonizacije, uz onu koja se odnosi na materiju ugovora u kan. 1290. CIC-a ( $c f$. kan. 1034. CCEO-a), dok se opće pravilo može naći u kan. 22. CIC-a (cf. kan. 1504. CCEO-a). Općenito o kanonizaciji $c f$. bilj. 10, a posebno glede zastare (praescriptio) u: Chiappeta, op. cit. u bilj. 10, str. 262 sq.; Beal; Coriden; Green, op. cit. u bilj. 1, str. 230; De Paolis, op. cit. u bilj. 2, str. 163; Škalabrin, op. cit. u bilj. 10, str. 48 sq.; 
razlike između dosjelosti i praescriptio (acquisitiva) svode na terminologiju i neke iznimne kanonske posebnosti. No što se tiče rimskog prava, ovdje se može istaknuti kako je praescriptio termin koji je izvorno označavao prigovor zastare zahtjeva zbog proteka određenog vremena, i to u obveznopravnom ili moguće i u stvarnopravnom smislu. ${ }^{27} \mathrm{U}$ klasičnom rimskom pravu postojala je tzv. longi temporis praescriptio kao prigovor posjednika protiv vlasničke tužbe zbog proteka određenog vremena, a vezano uz vlasništvo na provincijskim zemljištima. ${ }^{28} \mathrm{Na}-$ posljetku, kod Justinijana je longi temporis praescriptio uz usucapio jedan od oblika dosjelosti, čiji je izvanredni oblik (što se tiče predmeta dosjedanja i pretpostavki) poznat i kao longissimi temporis praescriptio. ${ }^{29}$ Zbog toga je već na načelnoj razini jasna snažna veza rimskog i kanonskog prava u području dosjelosti ili zastare, a terminološka (površinska) nesuglasja sa suvremenim pravom evidentno se mogu pripisati preuzimanju različitih elemenata rimskog uređenja tijekom recepcije rimskog prava.

Kako je već napomenuto, kanonsko pravo načelno preuzima (kanonizira) svjetovno pravo u pogledu zastare (praescriptio), što izrijekom navodi CIC u kan. 197. te CCEO u kan. 1540. U konkretnom slučaju to znači da je kanonsko pravo načelno preuzelo uređenje dosjelosti koje predviđa $\mathrm{ZV} .{ }^{30}$ Ovdje nema potrebe iznositi detalje navedenog uređenja. Ukratko, dosjelošću se vlasništvo stječe ako postoji sposobnost dosjedatelja i stvari koja se dosjeda, ako dosjedatelj ima stvar u samostalnom posjedu određene kakvoće te ako protekne zakonom određeno vrijeme. ${ }^{31}$ Što se tiče kakvoće, ako je posjed zakonit, istinit i pošten, bit će riječ

Brkan, op. cit. u bilj. 9 (Zastara), str. 376 te glede ugovora u: Chiappeta, op. cit. u bilj. 16, str. 588 sqq.; Beal; Coriden; Green, op. cit. u bilj. 1, str. 1492 sq.; De Paolis, op . cit. u bilj. 2, str. 248 sqq.; Pranjić, op. cit. u bilj. 13, str. 214 sq.; Škalabrin, op. cit. u bilj. 10, str. 115 sq.; Brkan, J., Ugovori i napose otuđenje, Služba Božja, vol. 45, br. 2, 2004. str. 8 - 36, str. 12 sqq.

27 Cf. Kaser, M., Das römische Privatrecht, vol. 1, C. H. Beck, München, 1971., str. 424.

28 Više o tomu u ibid., str. 424 sq.; Guarino, A., Diritto privato romano, Jovene, Napoli, 2001., str. 695 sqq. s uputama na izvore i daljnju literaturu.

29 Više o tomu u: Kaser, M., Das römische Privatrecht, vol. 2, C. H. Beck, München, 1975., str. 285 sqq. s iscrpnim uputama na izvore i daljnju literaturu.

30 Cf. iscrpnije o tomu posebno Brkan, op. cit. u bilj. 9 (Zastara) te Pranjić, op. cit. u bilj. 13, str. 178 sqq.; Škalabrin, op. cit. u bilj. 10, str. 47 sqq.

31 Vidi čl. 159. i 160. ZV-a. Cf. Klarić; Vedriš, op. cit. u bilj. 21, str. 275 sqq.; Gavella et al., op. cit. u bilj. 21, str. 556 sqq. Sposobnost dosjedatelja odnosi se na njegovu opću pravnu sposobnost (više o tomu u: Klarić; Vedriš, op. cit. u bilj. 21, str. 33), a stvar je sposobna za dosjedanje ako uopće može biti predmet prava vlasništva (više o tomu u: Klarić; Vedriš, op. cit. u bilj. 21, str. 74 sq.; Gavella et al., op. cit. u bilj. 21, str. 67 sqq.). Posjed je samostalan ako dosjedatelj posjeduje stvar kao da je njezin vlasnik 
o redovitoj dosjelosti kod koje treba proteći tri godine za pokretnine, a deset za nekretnine. ${ }^{32}$ No ako je posjed samo pošten, može nastupiti izvanredna dosjelost, ali tek nakon deset godina za pokretnine te dvadeset za nekretnine. Naposljetku, hrvatski zakonodavac predvidio je i posebne rokove za stvari koje su u vlasništvu određenih specifičnih subjekata kao što su RH, jedinice lokalne samouprave i uprave i sl., a njima je dodao i stvari u "vlasništvu crkve", kao i "drugih pravnih osoba koje ne traže za sebe dobitak, nego služe za dobrotvorne ili druge općekorisne svrhe”. Tako je za navedene stvari rok dvostruko dulji od ranije navedenih. ${ }^{33} \mathrm{U}$ svakom slučaju, može se reći kako općenito dosjelost hrvatskog prava slijedi osnovne strukture iz rimskog prava i rimske pravne tradicije. ${ }^{34}$

Međutim, u CIC-u je uz opće preuzimanje svjetovnog uređenja istaknuta i važna rezerva, "uz izuzetke koje određuju kanoni ovoga Zakonika", a odgovarajuću odredbu ima i CCEO. ${ }^{35}$ Oba zakonika sadržavaju određene specifičnosti u tom pogledu, točnije što se tiče rokova, predmeta posjedovanja te dobre vjere (bona fides). ${ }^{36}$ Tako su za određene slučajeve predviđeni posebni rokovi ${ }^{37}$, a za

(više o tomu u: Klarić; Vedriš, op. cit. u bilj. 21, str. 199; Gavella et al., op. cit. u bilj. 21, str. 170).

32 Zakonitost se odnosi na postojanje valjanog pravnog temelja za posjedovanje (čl. 18. st. 1. ZV-a), istinitost na stjecanje posjeda do kojega nije došlo silom, potajno, prijevarom ili zloporabom povjerenja (čl. 18. st. 2. ZV-a), a poštenje na to da posjednik prilikom stjecanja posjeda nije znao niti je imao razloga sumnjati da mu ne pripada pravo na posjed (čl. 18. st. 3. ZV-a). Više o tim karakteristikama posjeda u: Gavella et al., op. cit. u bilj. 21, str. 217 sqq.; Klarić; Vedriš, op. cit. u bilj. 21, str. 203 sqq.

33 Za stvari u "vlasništvu crkve" (zapravo, što se tiče $\mathrm{KC}$-a, u vlasništvu crkvenih pravnih osoba koje uređuju CIC i CCEO) predviđen je rok dosjelosti od 20 godina ako je riječ o pokretninama te 40 godina ako je riječ o nekretninama. $C f$. o tomu u perspektivi rimske pravne tradicije u: Petrak, M., Traditio iuridica: Quadraginta annorum praescriptio, Informator, vol. 64, br. 6416, str. 3 s uputama na izvore. Implikacije vezano uz različite rokove koje predviđa kanonsko pravo i navedena odredba analiziraju se u: Petrak, op. cit. u bilj. 5 (Codex), str. 697 sqq.

34 Naime, u rimskoj pravnoj tradiciji za dosjelost se u osnovi tražilo ispunjenje pretpostavki koje se mogu sistematizirati u heksametru res habilis, titulus, fides, possessio, tempus (cf., primjerice, Petrak, op. cit. u bilj. 24, str. 3; Schrage, E. J. H., Res habilis, titulus, fides, possessio, tempus. A medieval mnemonic hexameter?, u: Sturm, F.; Thomas, P.; Otto, J, Liber amicorum Guido Tsuno, Vico Verlag, Frankfurt am Main, 2013., str. 341 - 355; Petrak, M., Traditio iuridica: Res habilis, titulus, fides, possessio, tempus, Informator, vol. 64, br. 6425, str. 3).

35 Vidi kann. 197. CIC-a i 1540. CCEO-a.

37 Kan. 1270. CIC-a za nekretnine, pokretne dragocjenosti (res pretiosae su stvari koje se odlikuju starinom, umjetnošću ili štovanjem ( $c f$. kann. 1019. CCEO-a i 1189. 
neke predmete, kao što su posvećene stvari (res sacrae), uspostavljen je poseban režim po kojemu je zastara (praescriptio) ograničena ili isključena. ${ }^{38}$ Za predmetnu analizu najvažnije je što se u kann. 198. CIC-a i 1541. CCEO-a kao pretpostavka uvodi i specifičan standard tzv. bogoslovne dobre vjere (bona fides theologica), koja mora postojati u početku i tijekom cijelog trajanja predviđenog roka. ${ }^{39}$ No prije daljnje analize svih relevantnih implikacija vezanih uz navedeno, potrebno je ukratko dati pregled razvoja pretpostavke dobre vjere (bona fides) u kontekstu dosjelosti u rimskoj pravnoj tradiciji.

\section{BONA FIDES KOD DOSJELOSTI (USUCAPIO, PRAESCRIPTIO) U RIMSKOJ PRAVNOJ TRADICIJI}

Bona fides se kao pretpostavka dosjelosti (usucapio) u rimskom pravu javila otprilike u 2. st. pr. Kr. ${ }^{40} \mathrm{U}$ osnovi, bona fides je postojala kad dosjedatelj nije znao za postojanje okolnosti koje bi smetale stjecanju, poput činjenice da stvar koja se dosjeda pripada nekom drugom, te su postojale samo određene specifične iznimke $u$ tom smislu. ${ }^{41}$ Pritom se navedeno neznanje ili zabluda nisu smjeli

CIC-a), koje zbog toga imaju poseban tretman u pogledu stjecanja, otuđivanja i upravljanja (cf. i kann. 638. § 3., 1220. § 2., 1283. t. 2 i 1292. § 2.); više o njima općenito u: De Paolis, op. cit. u bilj. 2, str. 57 sq.; Škalabrin, op. cit. u bilj. 10, str. 23 sq.) te prava i tužbe ako pripadaju Apostolskoj Stolici predviđa rok od 100 godina, a ako pripadaju drugoj crkvenoj javnoj pravnoj osobi - 30 godina. Kan. 1019. CCEO-a za iste predmete predviđa iste rokove $\mathrm{u}$ pogledu Apostolske Stolice ili druge pravne osobe, no poseban rok od 50 godina predviđen je za navedene predmete ako pripadaju kojoj samosvojnoj Crkvi ili eparhiji. Više o tomu u: Brkan, op. cit. u bilj. 9 (Zastara), str. 382 sq.; Pranjić, op. cit. u bilj. 13, str. 179 sqq.; Škalabrin, op. cit. u bilj. 10, str. 50 sq.; cf. posebno Petrak, op. cit. u bilj. 5 (Codex), str. 699 sqq.

Cf. kann. 199. i 1269. CIC-a te 1542. i 1018. CCEO-a. Iscrpnije o tomu u: Brkan, op. cit. u bilj. 9 (Zastara), str. 386 sqq.; Pranjić, op. cit. u bilj. 13, str. 179; Škalabrin, op. cit. u bilj. 10, str. 49 sq.

Cf. Brkan, op. cit. u bilj. 9 (Zastara), str. 384 sqq.; Škalabrin, op. cit. u bilj. 10, str. 51 sq. Cf. Kaser, op. cit. u bilj. 27, str. 423 te analiza u Mayer-Maly, T., Studien zur Frühgeschichte der Usucapio III, Zeitschrift der Savigny-Stiftung für Rechtsgeschichte, Romanistische Abteilung, vol. 79, br. 1, str. 86 - 107, str. 97 sqq., sve s iscrpnim uputama na izvore i daljnju literaturu.

${ }^{41}$ Kaser, op. cit. u bilj. 27, str. 422 sq.; Hausmaninger, H., Die bona fides des Ersitzungsbesitzers im klassischen römischen Recht, Herold, Wien, 1964., str. 78. Iznimke se odnose, primjerice, na situaciju u kojoj je res mancipi prenesena tradicijom umjesto mancipacijom, ili ako je res mancipi bila fiducijarno prenesena, a zatim neformalno vraćena ( $c f$. o tomu Apostolova Maršavelski, M., O Gajevu osvrtu na institut usureceptio fiduciae, Zbornik Pravnog fakulteta u Zagrebu, vol. 52, br. 5, 2002., str. 
odnositi na pravo već na činjenice, odnosno nije smjela biti riječ o error iuris. ${ }^{42}$ Bona fides se tražila vezano uz usucapio, ali i za longi temporis praescriptio klasičnoga rimskoga prava, a zadržana je i u svim oblicima dosjelosti Justinijanova prava (usucapio, longi i longissimi temporis praescriptio). ${ }^{43}$ Teret dokaza bio je u pravilu na onomu tko je tvrdio da postoji mala fides, drugim riječima, bona fides se predmnijevala (bona fides praesumitur). ${ }^{44}$ Također, bona fides se u pravilu tražila samo na početku stjecanja posjeda, a ne i u njegovu naknadnom tijeku, što je sažeto $\mathrm{u}$ reguli mala fides superveniens non nocet. ${ }^{45}$

Kako je već istaknuto ranije, cjelokupno uređenje vezano uz dosjelost iz rimskoga prava bilo je predmet njegove recepcije. Međutim, u kontekstu kanonističke doktrine vrlo rano se kao problematično istaknulo traženje dobre vjere samo na početku posjedovanja, a ne i naknadno. Tako je više autora još u 12. st. isticalo kako bona fides treba postojati cijelim tijekom roka, glede crkvene imovine, ali i općenito. Osnovni problem bio je teološke i moralne naravi jer se smatralo kako bez dobre vjere zadržanje stvari koja nekomu ne pripada zapravo konstituira grijeh, odnosno povredu sedme Božje zapovijedi (non furtum facies). ${ }^{46}$ Navedeni stav dobio je svoju potvrdu na Četvrtom lateranskom saboru 1215., gdje je utvrđeno kako ni kanonska ni civilna praescriptio ne vrijede ako bilo kad tijekom roka izostane dobra vjera, odnosno nastane svijest o tomu da je stvar tuđa. ${ }^{47}$ Takva impostacija zahtjeva dobre vjere ističe

917 - 932). Naime, u tim situacijama je stjecatelju poznato da postoji prepreka stjecanja, ali s obzirom na to da zapravo nema nepoštenja, bona fides nije narušena (cf. Kaser, op. cit. u bilj. 27, str. 423).

42 Kaser, op. cit. u bilj. 27, str. 423 te analiza u: Daube, D., Mistake of Law in Usucapion, The Cambridge Law Journal, vol. 16, br. 1, 1958., str. 85 - 92, sve s uputama na izvore i daljnju literaturu.

43 Kaser, op. cit. u bilj. 27, str. 424 sq.; Guarino, op. cit. u bilj. 28, str. 698 sq.; Kaser, op. cit. u bilj. 29, str. 285 sqq., s uputama na izvore i daljnju literaturu.

44 Kaser, op. cit. u bilj. 27, str. 423. Za navedenu regulu $c f$. Petrak, M., Traditio iuridica: Bona fides praesumitur, Informator, vol. 56, br. 5646, str. 3.

45 U prijevodu: Naknadna zla vjera ne škodi. Cf. Kaser, op. cit. u bilj. 27, str. 423; Hausmaninger, op. cit. u bilj. 41, str. 81 sqq.

46 Dondorp, H., Bona fides praesumitur in classical Canon law, Zeitschrift der SavignyStiftung für Rechtsgeschichte, Kanonistische Abteilung, vol. 102, br. 1, 2016., str. 99 - 122, str. 100 sqq.

47 Quoniam omne quod non est ex fide peccatum est, synodali iudicio diffinimus, ut nulla valeat absque bona fide praescriptio tam canonica quam civilis, cum generaliter sit omni constitutioni atque consuetudini derogandum quae absque mortali peccato non potest observare. Unde oportet ut qui praescribit in nulla temporis parte rei habeat conscientiam alienae (cf. ibid., str. 
se kao ključno obilježje kanonskopravne praescriptio, oživotvoreno u kann. 198. CIC-a i 1541. CCEO-a. ${ }^{48}$

Štoviše, navedeni oblik pretpostavke dobre vjere kod dosjelosti bio je preuzet $\mathrm{u}$ ius commune, na temelju čega u određenom obliku postoji i u nekim suvremenim pravnim poredcima. ${ }^{49}$ Među njih se može uvrstiti i hrvatsko pravo, vezano uz koje se izričito spominje kanonsko pravo kao izvor inspiracije za odgovarajuću odredbu u ZV-u (suvremeni čl. 18. st. 3. u vezi s čl. 159.), te se navodi kako je ranije spomenuta rimska regula tako preformulirana u mala fides superveniens nocet. ${ }^{50}$ Međutim, valja istaknuti kako zahtjev dobre vjere, odnosno standard poštenja posjeda u hrvatskom pravu, nije isti na početku i tijekom trajanja roka dosjelosti. Naime, čl. 159. ZV-a upućuje na poštenje posjeda kao pretpostavku dosjelosti, a ona je precizirana u čl. 18. st. 3. istoga zakona. Prema navedenomu poštenje posjeda postoji ako posjednik prilikom stjecanja nije znao niti je s obzirom na okolnosti imao dovoljno razloga posumnjati da mu ne pripada pravo na posjed (odnosno, relevantno je znanje ili mogućnost znanja), ali u naknadnom razdoblju će poštenje prestati jedino ako posjednik baš dozna da mu ne pripada

100; Urquiri, T., Cuestiones canónicas aldredor de la buena fe necesaria para la prescripcion, Revista Española de Derecho Canónico, vol. 8, br. 22, 1953., str. 89 - 119, str. 95).

48 Cf. Chiappeta, op. cit. u bilj. 10, str. 263; De Paolis, op. cit. u bilj. 2, str. 165 sq.; Beal; Coriden; Green, op . cit. u bilj. 1, str. 231 te u domaćoj literaturi Brkan, op. cit. u bilj. 9 (Zastara), str. 384 sqq.; Škalabrin, op. cit. u bilj. 10, str. 51 sq. Općenito o kanonističkoj dobroj vjeri u CIC-u iz 1983. u: Albisetti, A., Riflessioni sulla bona fides canonistica dopo il Codex del 1983, u: Studi in onore di Gaetano Catalano, vol. I, Rubbettino, Soveria Mannelli, 1998., str. 19 - 26. Povijest razvoja kanonističke dobre vjere u području zastare (praescriptio) u starijoj literaturi obrađena je u: Hildenbrand, K., Geschichte der Bestimmungen des canonischen Rechtes über die bona fides bei der Ersitzung und Klagverjährung, Archiv für die civilistische Praxis, vol. 36, br. 1, 1853., str. 27 - 49 te monografski u: Ruffini, F., La buona fede nella materia di prescrizione. Storia della teoria canonistica, Fratelli Bocca, Torino, 1892.

49 Cf. Scavo Lombardo, L., Buona fede (dir. can.), u: Moratti, C.; Pugliatti, S., Enciclopedia del diritto, vol. V, Giuffré, Milano, 1959., str. 664 - 677, str. 671 sqq.; Wieling, H. J., Sachenrecht, Bd. 1, Springer, Berlin, 2006., str. 421 te što se tiče, primjerice, suvremenog njemačkog prava ibid., str. 422 sq., a austrijskog Iro, G., Sachenrecht, Verlag Österreich, Wien, 2016., str. 151. Nasuprot tomu, npr. u francuskom pravu na načelnoj razini prihvaćena je rimska regula u izvornom obliku prema kojoj se traži dobra vjera samo na početku posjedovanja (cf. Terré, F.; Simler, P., Droit civil: Les biens, Dalloz, Paris, 2014., str. 375).

50 U prijevodu: Naknadna zla vjera škodi. Cf. Gavella, N., O dosjelosti kao ustanovi našeg pravnog uređenja, Zbornik Pravnog fakulteta u Zagrebu, vol. 26, br. 3, 1976., str. 241 - 269, str. 247; Gavella, N., Posjed stvari i prava, Narodne novine, Zagreb, 1980., str. 85; Gavella et al., op. cit. u bilj. 21, str. 221. 
pravo na posjed, a ne i ako je samo imao mogućnost to doznati. U literaturi se kao razlog za navedeni stav zakonodavca navodi kako ne bi bilo opravdano od posjednika očekivati da nakon stjecanja posjeda stalno preispituje svoj pravni položaj. ${ }^{51}$ Osim toga, navodi se kako je poštenje posjeda negativno koncipirano, u smislu što kod njega posjednik ne zna (i ne može znati) da nema pravo, a nije potrebno da je u zabludi kako ima pravo na posjedovanje. ${ }^{52}$ Pritom je vezano uz navedeno potrebno primijeniti pažnju kakvu bi primijenila uobičajeno pažljiva osoba u odgovarajućim okolnostima, drugim riječima, primjenjuje se standard culpa lata. ${ }^{53}$ Poštenje posjeda općenito se predmnijeva, odnosno smatra se da ono postoji dok se ne dokaže suprotno (čl. 18. st. 5. ZV-a). ${ }^{54}$ Naposljetku, poštenje posjeda kad je posjednik pravna osoba prosuđuje se prema poštenju i postupanju fizičke osobe koja je za tu pravnu osobu ovlaštena poduzimati čine stjecanja ili izvršavanja posjeda (čl. 18. st. 6. ZV-a). ${ }^{55}$

\section{KANONISTIČKA BONA FIDES I NJEZINE POSEBNOSTI U ODNOSU NA POŠTENJE POSJEDA}

Stav kanonskog prava što se tiče dobre vjere kod zastare (praescriptio) na normativnoj razini izražen je u već spomenutim kann. 198. CIC-a i 1541. CCEO-a, koji ističu kako nikakva zastara ne vrijedi ako se ne temelji na dobroj vjeri u početku i tijeku svega vremena koje se zahtijeva. ${ }^{56}$ No osim toga, s obzirom na to da je CIC u pogledu zastare (praescriptio) sadržajno bitno preuzeo uređenje koje je imao prethodni Codex Iuris Canonici iz 1917., djelovanjem kan. 6. § 2. $\mathrm{CIC}-\mathrm{a}^{57}$ potrebno je u obzir uzeti i kanonsku predaju u navedenom području. U kontekstu svega navedenog najprije treba navesti kako se u kanonskoj doktrini redovito ističe kako je standard koji se traži tzv. bona fides theologica, nasuprot

51 Gavella, op. cit. u bilj. 50 (Posjed), str. 86; Gavella et al., op. cit. u bilj. 21, str. 222.

52 Cf. Hadžić, A., Dosjelost kao stvarnopravni institut u pravnim porecima kontinentalnoeuropskoga pravnog kruga i pozitivnoj sudskoj praksi, Europski pokret, Grafika, Osijek - Split, 2005., str. 115 sq.

53 Cf. Gavella, op. cit. u bilj. 50 ( $O$ dosjelosti), str. 246; Gavella et al., op. cit. u bilj. 21, str. 221.

54 Cf. Gavella et al., op. cit. u bilj. 21, str. 221; Klarić; Vedriš, op. cit. u bilj. 21, str. 206.

55 Cf. Gavella et al., op. cit. u bilj. 21, str. 222; Klarić; Vedriš, op. cit. u bilj. 21, str. 207.

56 Iznimke su predviđene jedino za zastaru kaznenih tužbi po kann. 1362. CIC-a i 1152. CCEO-a.

57 Općenito o toj odredbi $c f$. Chiappeta, op. cit. u bilj. 10, str. 14; Beal; Coriden; Green, op. cit. u bilj. 1, str. 55 . 
svjetovnoj dobroj vjeri koja se naziva bona fides iuridica. Pritom je razlika u tomu što se bona fides theologica odnosi na stvarno stanje vezano uz vlastitu savjest, dok je bona fides iuridica pravni standard kojega pravni poredak predmnijeva i koji može postojati bez obzira na stvarno stanje savjesti..$^{58}$ Navedena definicija upućuje da je načelno riječ o moralnoj kategoriji, s obzirom na to da će u pravilu biti teško ili nemoguće utvrditi privatno stanje nečije savjesti. Stoga se još u starijoj kanonističkoj doktrini isticalo kako se i tamo bona fides predmnijeva in foro externo, odnosno u pogledu njezine vanjske manifestacije, sve dok se ne dokaže suprotno. ${ }^{59} \mathrm{Tu}$ je zapravo riječ o primjeni regule praesumitur ignorantia, ubi scientia non probatur (predmnijeva se neznanje tamo gdje se znanje ne može dokazati), iz poznate kanonističke zbirke regula Liber Sextus pape Bonifacija VIII. iz 1298. (br. 47), koja svoju relevantnost ima i u kanonskom, ali i u hrvatskom pravu. ${ }^{60}$ No tu se može postaviti pitanje koji je sadržaj navedenog standarda dobre vjere, odnosno što je to što se predmnijeva dok se ne dokaže suprotno.

U kanonističkoj literaturi navodi se kako je riječ o privatnom uvjerenju, razumnom te makar i neskrivljeno pogrešnom, kako se ne vrijeđaju tuđa prava, odnosno kako se posjeduje vlastita, a ne tuđa stvar. ${ }^{61}$ Dakle, laka ili obična nepažnja (negligentia levis), kao ni u hrvatskom pravu, neće utjecati na dobru vjeru te je očito i tu potrebna culpa lata. ${ }^{62}$ Pritom se traži postojanje takozvane pozitivne dobre vjere (bona fides positiva), odnosno uvjerenja kako s jedne strane postoji vlastito pravo na posjedovanje te ujedno s druge strane ne postoji tuđe

58 Cf. Chiappeta, op. cit. u bilj. 10, str. 199; De Paolis, op. cit. u bilj. 2, str. 165; Urquiri, op. cit. u bilj. 47, str. 92 sqq.; Albisetti, op. cit. u bilj. 48, str. 20 sqq.; Brkan, op. cit. u bilj. 9 (Zastara), str. 386; Škalabrin, op. cit. u bilj. 10, str. 51.

59 Navedeno pravilo ističe još poznati teolog i kanonist iz 17. st. Anacletus (Johann Georg) Reiffensteuel (više o njemu u: Marthaler, B. L. (ur.), New Catholic Encyclopedia, vol. 12, Gale, Detroit, 2003., str. 34 (unos Reiffensteuel, Anacletus (Johan Georg)) u svojemu djelu Tractatus de regulis juris ( $c f$. Zuffellato, A., Il Tractatus de regulis juris di Anacleto Reiffensteuel: spunti critici per una traduzione ragionata (doktorska disertacija), Padova, 2014. (http://paduaresearch.cab.unipd.it/6405/ (9. prosinca 2020.)), str. 116.

60 Cf. o tomu posebno Petrak, op. cit. u bilj. 5 (Izvori), str. 259 sqq. Autor vrlo korisno navodi i cjelovit popis svih relevantnih regula uz prijevod na hrvatski u ibid., str. 275 sqq. (cf. i Petrak; Staničić, op. cit. u bilj. 5, str. 357 sqq.) te je otuda preuzet prijevod navedene regule.

${ }_{61}$ Cf. Chiappeta, op. cit. u bilj. 10, str. 263; De Paolis, op. cit. u bilj. 2, str. 165; Urquiri, op. cit. u bilj. 47, str. 90 .

$62 C f$. još u starijoj literaturi Migne, J.-P. (ur.), Theologiae cursus completus, tomus decimus-quintus, Apud editore in Via Gallicè dicta, Parisiis, 1839., str. 867. 
pravo koje bi se vrijeđalo. ${ }^{63}$ Osim toga, odredbe sadržane u kann. 198. CIC-a i 1541. CCEO-a evidentno ne prave nikakvu razliku između početka posjedovanja i naknadnog tijeka roka zastare (praescriptio), zbog čega je jasno da u njegovu cijelom tijeku postoji isti standard. ${ }^{64}$

Zbog svega navedenog, iako je činjenica da se i poštenje posjeda u hrvatskom pravu i bona fides $\mathrm{u}$ kanonskom pravu predmnijevaju, ipak postoje bitne razlike između dva standarda. Oni će doći do izražaja tek ako zainteresirana stranka ponudi protudokaz, ali taj protudokaz moći će se odnositi na različite stvari u svakom pojedinom sustavu. U hrvatskom pravu protudokaz će se odnositi na znanje ili mogućnost znanja prilikom stjecanja posjeda, a u njegovu naknadnom tijeku samo na znanje, ali ne i na njegovu mogućnost. S druge strane, u kanonskopravnom kontekstu protudokaz se može odnositi na razumnu mogućnost znanja u početku i cijelim tijekom roka. Osim toga, u hrvatskom će pravu protivnik dosjedanja trebati dokazati da je dosjedatelj znao (odnosno prilikom stjecanja posjeda i mogao znati) da mu ne pripada pravo na posjed. No u kanonskom pravu, gdje se dobra vjera odnosi na predmnijevano uvjerenje o vlastitom pravu te izostanak vrijeđanja tuđeg prava, protudokaz će se moći odnositi na jedno ili na drugo, dakle na znanje ili mogućnost znanja da ne postoji vlastito pravo ili da postoji tuđe. Ovisno o okolnostima, dakle, dokazi će se sadržajno nekad jednostavno odnositi na različite stvari. ${ }^{65}$ Naposljetku valja napomenuti kako

63 Cf. Beal; Coriden; Green, op. cit. u bilj. 1, str. 231; Lumbreras, P., Casus conscientiae antiqui et recentiores, Pontificium Athenaeum "Angelicum", Romae, 1963., str. 71 sq.

64 U tom smislu se tijekom revizije CIC-a iz 1983. navodilo kako uopće nema potrebe isticanja početka tijeka roka jer je on sadržan u izrazu koji navodi kako u cijelom tijeku roka treba postojati bona fides (cf. De Paolis, op. cit. u bilj. 2, str. 165, bilj. 56). Iako nomotehnički gledano zaista nema potrebe posebnog navođenja početka roka, on je postojao te postoji i dalje u izrazu kanonističke regulative vjerojatno zbog činjenice da se u rimskom pravu u obzir uzimao samo početak te je u odluci ranije spomenutog Četvrtog lateranskog sabora trebalo uz početak posebno istaknuti i cjelokupni tijek, što se zatim odrazilo i u naknadnim formulacijama istoga pravila.

65 Osim svega navedenog, u starijoj kanonističkoj literaturi raspravljalo se i o tomu dostaje li u kanonskom pravu bona fides theologica čak i ako ne postoji bona fides iuridica. Navedeno je zamislivo u situaciji kad bi se predmnjeva dobre vjere srušila dokazom o njezinu vjerojatnom izostanku, na što bi se uzvratilo protudokazom o tomu da u pogledu privatne savjesti dobra vjera ipak nije bila narušena (primjerice, preko prisege kojoj bi pravni poredak dao dokaznu snagu). Zauzet je stav kako će bona fides theologica dostajati jedino u slučajevima u kojima svjetovno zakonodavstvo uopće ne traži dobru vjeru ( $c f$. Carrière, J., Justitia et jure, Apud Mequignon juniorem, Parisiis, 1839., str. 86 sqq.; Migne, op. cit. u bilj. 62, str. 868). S obzirom na okolnost da se kod dosjelosti u ZV-u beziznimno traži bona fides, odnosno poštenje posjeda, navedeno pravilo nema relevantnost u suvremenom hrvatskom kontekstu. 
je glede pravnih osoba u kanonskom pravu relevantna dobra vjera upravitelja koji su u skladu s kanonskim pravom zaduženi za crkvena dobra u navedenim pravnim osobama. ${ }^{66}$

\section{SUVREMENI PRAVNI OKVIR I POTENCIJALNE IMPLIKACIJE}

U prethodnom tekstu obrađena je problematika standarda dobre vjere (bona fides) kod kanonskopravne zastare (praescriptio acquisitiva) te se može postaviti pitanje koja je relevantnost svega navedenog u kontekstu suvremenog hrvatskog prava. Radi odgovora na navedeno pitanje potrebno je krenuti od temeljnog uređenja pravnog položaja crkvenih pravnih osoba i njihove imovine u RH. Kako je već napomenuto, ustavna odredba o pravnoj snazi međunarodnih ugovora otvorila je prostor primjeni potencijalnih posebnosti uređenja u ugovorima između Svete Stolice i RH što se tiče crkvenih pravnih osoba i njihove imovine. U predmetnom kontekstu tu je najvažniji Ugovor o pravnim pitanjima, i to njegov čl. 10. st. 1. koji propisuje sljedeće: Crkvene pravne osobe mogu kupovati, posjedovati, koristiti ili otudivati pokretna i nepokretna dobra te stjecati i otudivati imovinska prava, prema odredbama kanonskoga prava i zakonodavstva Republike Hrvatske. Trenutačno najvažniji elementi ove odredbe su sljedeći. Najprije, ona se ratione personae odnosi na crkvene pravne osobe, drugim riječima pravne osobe kanonskoga prava. ${ }^{67}$ Na temelju kan. 1257. CIC-a, koji kanonsko imovinskopravno uređenje vezuje uz javne pravne osobe u Crkvi, ovo će se ponajprije odnositi na njih, drugim riječima na partikularne Crkve (kan. 373. CIC-a), crkvene pokrajine (kan. 432. CIC-a), biskupske konferencije (kan. 449. CIC-a), sjemeništa (kan. 238. CIC-a), župe (kan. 515. CIC-a), kanonske ustanove, provincije i pojedine kuće (kan. 634. CIC-a), družbe apostolskoga života i njihove dijelove i kuće (kan. 741. CIC-a) itd. ${ }^{68}$ Uzevši u obzir specifični hrvatski kontekst, odnosno postojanje Križevačke eparhije i pripadajućih župa, relevantne su i odredbe kann. 1008. i

${ }_{66}$ Cf. Brkan, op. cit. u bilj. 9 (Zastara), str. 385; Urquiri, op. cit. u bilj. 47, str. 112 sqq. Iscrpnije o upraviteljima u: Chiappeta, op. cit. u bilj. 16, str. 560 sqq.; Beal; Coriden; Green, op. cit. u bilj. 1, str. 1474 sqq.; De Paolis, op. cit. u bilj. 2, str. 187 sqq.; Pranjić, op. cit. u bilj. 13, str. 185 sqq.; Škalabrin, N., Upravljanje dobrima, Bogoslovska smotra, vol. 75, br. 1, 2005., str. 343 - 379; Škalabrin, op. cit. u bilj. 10, str. 69 sqq.

67 Pravne osobe kanonskoga prava uređene su na načelnoj razini u kann. 113. - 123. CIC-a. Više o tomu u: Chiappeta, op. cit. u bilj. 10, str. 138 sqq.; Beal; Coriden; Green, op. cit. u bilj. 1, str. 154 sqq.; Brkan, J., Pravne osobe (kan. 113-123), Služba Božja, vol. 34, br. 2, 1994., str. 99 - 124.

68 Cf. Chiappeta, op. cit. u bilj. 10, str. 143. 
1009. CCEO-a, koji upućuju na primjenu kanonskog imovinskopravnog uređenja na pravne osobe, dakle i na eparhije i župe (kann. 921., 177. i 279. CCEO-a).

Nadalje, citirana odredba upućuje kako će se na stjecanje i otuđivanje imovinskih prava od strane crkvenih pravnih osoba primjenjivati odredbe kanonskog prava i zakonodavstva RH. Nema nikakve dvojbe kako je zastara (praescriptio acquisitiva) način stjecanja imovinskog prava, točnije vlasništva, u kanonskom pravu, kao što je i dosjelost u hrvatskom pravu. ${ }^{69}$ Stoga se ova odredba jasno odnosi na situacije kad crkvene pravne osobe stječu vlasništvo zastarom (praescriptio acquisitiva), odnosno dosjelošću hrvatskog prava, od bilo koje druge osobe. Što se tiče otuđivanja ili otuđenja (alienare, tj. alienazione iz čl. 10. Ugovora o pravnim pitanjima u talijanskoj verziji, koja je uz hrvatsku službeni tekst, odnosno alienatio u kanonskom pravu), tu najprije valja napomenuti kako je u kanonskopravnoj doktrini riječ o specifičnom i višeznačnom pojmu, koji nije istovjetan s istoimenim građanskopravnim konceptom. ${ }^{70} \mathrm{U}$ kanonskom pravu tako postoji otuđenje u užem smislu koje se odnosi na prijenos prava vlasništva prodajom ili darivanjem. No postoji i otuđenje u širem smislu koje se odnosi na bilo koju radnju ili djelovanje kojom se pogoršava imovinsko stanje crkvene pravne osobe. ${ }^{71}$ Pritom se u literaturi navodi kako navedeno uključuje i negativne radnje poput odricanja od nekog prava, primjerice nasljedstva ili darovanja, pa čak i napuštanje stvari ili prava. ${ }^{72}$ Može li se pod navedeno svrstati gubitak vlasništva na imovini crkvene osobe zbog stjecanja vlasništva dosjelošću od strane neke druge osobe? Iako taj slučaj nije u literaturi izrijekom naveden, kanonskopravni koncept otuđenja čini se dovoljno široko koncipiran da bi ga uključivao. To bi vrijedilo posebno ako se u obzir uzmu obveze upravitelja po kann. 1284. - 1289. CIC-a i 1028. - 1033. CCEO-a, čija je funkcija, među ostalim, i očuvanje crkvene imovine. Tako bi moglo doći do zanemarivanja navedenih obveza nereagiranjem na nečije dosjedanje crkvene imovine. Zanemarivanjem obveza bi upraviteljevim nečinjenjem, koje je kao propust zapravo samo naličje činjenja ( $c f$. u tom smislu

69 Cf. kann. 1268. CIC-a i 1540. CCEO-a.

70 Za otuđenje u građanskopravnoj doktrini cf. Gavella et al., op. cit. u bilj. 21, str. 112 sqq.

71 U kanonističkoj doktrini izrijekom se navodi kako može biti riječ o "qualsiasi atto, operazione o negozio" (Chiappeta, op. cit. u bilj. 16, str. 590). Sustavan i iscrpan pregled stavova o tomu što je alienatio kanonskog prava u literaturi, uključujući onu prije i poslije CIC-a, donosi De Paolis, op. cit. u bilj. 2, str. 282 sqq. Cf. Beal; Coriden; Green, op. cit. u bilj. 1, str. 1493 sqq.; Škalabrin, op. cit. u bilj. 10, str. 118 sqq.; Brkan, op. cit. u bilj. 26, str. 16 sqq.; Pranjić, op. cit. u bilj. 13, str. 216 sqq.

72 Cf. Chiappeta, op. cit. u bilj. 16, str. 590; De Paolis, op. cit. u bilj. 2, str. 284 sq. 
i regulu et non facere, facere est iz rimske pravne tradicije ${ }^{73}$ moglo doći do gubitka vlasništva i zacijelo pogoršanja imovinskog stanja crkvene pravne osobe. Navedenom argumentu posebno bi u korist išla činjenica kako se i u samom rimskom pravu dosjelost (usucapio) nekad smatrala otuđenjem (alienatio) iz perspektive osobe čija se imovina dosjedala. Tako se $\mathrm{u}$ fragmentu kasnoklasičnog pravnika Paula D. 50, 16, 28 (Paul. 21 ad ed.) u bitnom dijelu navodi sljedeće: "alienationis" verbum etiam usucapionem continet: vix est enim, ut non videatur alienare, qui patitur usucapi. ${ }^{74}$ Osim toga, Gaj, jedan od najpoznatijih klasičnih rimskih pravnika, u Gai. Inst. 2, 65 usucapio (dosjelost) svrstava u načine otuđenja (alienatio) koji pripadaju u ius civile..$^{75}$ Sve u svemu, izgleda kako postoje ozbiljni i uvjerljivi argumenti koji upućuju na to da se čl. 10. st. 1. Ugovora o pravnim pitanjima odnosi i na situaciju kad imovinu crkvene pravne osobe dosjelošću stječe bilo

73 U prijevodu: i nečinjenje je činjenje. Navedeno proizlazi iz jednog fragmenta klasičnog pravnika Paula (D. 50, 17, 121 (Paul. 13 ad ed.)), koji u bitnom dijelu glasi: Qui non facit quod facere debet, videtur facere adversus ea, quia non facit, koju je poznati pravnik iz 16. st. Jacobus Cujacius (Jacques Cujas) preformulirao u navedeni izraz (cf. Jacobi Cujacii Opera, tomus sestus, Ex officina frate. Giachetti, Prati, 1838., str. 2106).

74 U prijevodu: Riječ “alienatio" (otuđenje, op. a.) također sadržava i dosjelost jer teško je smatrati da nije otuđio onaj tko je dopustio dosjedanje.

75 Cf. također u tom smislu i D. 41, 1, 66 (Ven. 6 interd.), gdje se usucapio implicirano navodi kao način otuđenja (alienatio). Izgleda da je alienatio u sustavu klasičnog rimskog prava značila prestanak jednog i nastanak drugog prava vlasništva na istoj stvari, čak i kad je do toga došlo bez volje prvotnog vlasnika, odnosno na temelju objektivnih razloga (kao što bi bili i protek vremena te ispunjenje ostalih pretpostavki za dosjelost) ( $c f$. Brasiello, Alienatio, u: Azara, A.; Eula, E. (ur.), Novissimo digesto italiano, vol. I/1, UTET, Torino, 1964., str. 480 - 481, str. 481; Brasiello, U., Alienatio, Studia et documenta historiae et iuris, vol. 15, 1949., str. 114 - 140, str. 127 sq.; cf. Pugliatti, S., Alienazione, u: Moratti, C.; Pugliatti, S., Enciclopedia del diritto, vol. II, Giuffré, Milano, 1958., str. 1 - 5, str. 2). U izvorima se nekad usucapio navodi uz otuđenje (alienatio) i bez posebna isticanja njihove veze (Ulp. Reg. 2, 3; D. 40, 5 , 24, 21 (Ulp. 5 fideic.); C. 7, 2, 13 (Diocl. et Max.)), što bi upućivalo i na prisutnost njihova mogućeg razlikovanja. U svakom slučaju izgleda kako je u postklasičnom pravu napravljen svojevrsni konceptualni pomak te se alienatio uglavnom počela poimati kao subjektivni i voljni prijelaz vlasništva (Brasiello, op. cit. u ovoj bilj. (Novissimo), str. 481), što je mogući temelj takvog koncipiranja otuđenja u suvremenoj građanskopravnoj doktrini. No bez obzira na navedene konceptualne nijanse u okviru rimskog pravnog sustava, činjenica da su neki rimski izvori poprilično jasno usucapio smatrali otuđenjem svakako je relevantna u kontekstu uređenja koja su dobrim dijelom temeljena na rimskom pravu i rimskoj pravnoj tradiciji, što kanonsko pravo nedvojbeno jest. Posebno je u tom smislu relevantan citirani Paulov fragment, koji izrijekom navodi dopuštanje dosjedanja (qui patitur usucapi), što bi se u predmetnom kontekstu moglo povezati s činjenjem, odnosno nečinjenjem upravitelja crkvene pravne osobe u pogledu njezine imovine. 
koji drugi pravni subjekt. To bi imalo smisla i uzevši u obzir činjenicu kako se navedeni članak sasvim nedvojbeno odnosi na praescriptio acquisitiva, a praescriptio extinctiva do koje dolazi iz perspektive crkvene pravne osobe kad netko stječe njezinu imovinu dosjelošću samo je druga strana iste medalje, odnosno, samo jedan oblik manifestacije kanonskopravne zastare (praescriptio).

Naposljetku preostaje sintagma koja u navedenim situacijama propisuje primjenu kanonskog prava i zakonodavstva RH. U literaturi je već istaknuto kako, uzimajući u obzir cjelokupni pravni okvir te podjednako kanonizaciju prava RH i uvažavanje iznimki koje propisuje kanonsko pravo, to zapravo znači kako je $\mathrm{u}$ navedenim slučajevima kanonsko pravo $\mathrm{u}$ načelu lex specialis. ${ }^{76}$ To konkretno znači kako će u tim slučajevima u pravilu doći do izražaja kanonskopravne posebnosti vezane uz zastaru (praescriptio acquisitiva), što je u literaturi već analizirano u pogledu duljine rokova. ${ }^{77}$ Dosadašnja argumentacija upućuje na to kako u istim slučajevima treba primijeniti standard dobre vjere koji uređuju kanonsko pravo i doktrina. Drugim riječima, kad crkvene pravne osobe stječu imovinu zastarom (praescriptio acquisitiva), odnosno dosjelošću, a izgleda i kad se na isti način stječe njihova imovina, u pogledu dobre vjere potrebno je primijeniti ranije obrazloženi standard sa svim njegovim specifičnostima.

\section{ZAKLJUČAK}

U radu je analiziran specifičan aspekt suodnosa i uzajamnog preklapanja kanonskog i suvremenog hrvatskog prava. U nastavku na nedavnu literaturu u kojoj su se sustavno obradila mnoga druga pitanja, analiza je usredotočena na problematiku dobre vjere (bona fides), tj. poštenja posjeda kao pretpostavke stjecanja vlasništva kanonskopravnom zastarom (praescriptio acquisitiva), odnosno dosjelošću hrvatskog prava. U skladu s već višestruko u literaturi istaknutim specifičnim uređenjem za pravne osobe $\mathrm{KC}$-a na temelju ustavno definirane nadzakonske snage ugovora između Svete Stolice i RH, i u tom pogledu ustanovljena je određena posebnost. Naime, dok načelno u pogledu zastare (praescriptio acquisitiva) kanonsko pravo kanonizira uređenje koje poznaje ZV, dobra vjera jedna je od iznimno specifičnih pretpostavki. U kanonskom pravu i doktrini tzv. bona fides theologica odnosno bogoslovna ili kanonistička dobra vjera odnosi se na privatno uvjerenje o postojanju vlastitog prava na posjedovanje te izostanak tuđeg prava koje bi se smetalo, dakle koncipirana je podjednako pozitivno i

\footnotetext{
76 Cf. Brkan, op. cit. u bilj. 9 (Zastara), str. 380, bilj. 18; Petrak, op. cit. u bilj. 5 (Codex), str. 701.

77 Petrak, op. cit. u bilj. 5 (Codex), str. 697 sqq.
} 
negativno. Osim toga, ona mora postojati jednako u početku i tijekom trajanja roka posjedovanja. Pritom u cijelom trajanju roka postoji isti standard, znanje ili razumna mogućnost znanja. Kao takva, kanonistička dobra vjera bitno se razlikuje od standarda poštenja posjeda u hrvatskom pravu. On je najprije definiran isključivo negativno, tako što se traži izostanak znanja ili mogućnosti znanja o vlastitom nepripadanju prava na posjed. Uz to, poštenje posjeda će se narušiti ako prilikom stjecanja posjeda postoji znanje ili mogućnost znanja navedene okolnosti, ali u naknadnom tijeku mogućnost znanja prestaje biti relevantna (bitno je isključivo saznanje). Iako oba pravna sustava, i kanonski i hrvatski, predmnijevaju dobru vjeru, odnosno poštenje posjeda, navedene razlike mogu doći do izražaja kod protudokaza zainteresirane stranke, dakle protivnika dosjedanja odnosno vlasnika stvari.

Djelovanjem čl. 10. st. 1. Ugovora o pravnim pitanjima, u svezi s čl. 134. Ustava RH, navedeno kanonističko uređenje dobilo je svoju relevantnost i izravnu primjenjivost u pravnom sustavu RH. Sasvim je nedvojbeno kako navedena odredba propisuje primjenu kanonskog prava vezano uz zastaru (praescriptio acquisitiva) kao način stjecanja prava vlasništva. Drugim riječima, specifičnosti kanonskopravnog uređenja, uključujući i pitanje dobre vjere, primjenjivat će se u svim slučajevima kad crkvene pravne osobe stječu imovinu zastarom (praescriptio acquisitiva). Ponuđena argumentacija, nadamo se, pokazala je kako postoje ozbiljni argumenti za njezinu primjenu i kad se istim načinom stječe imovina crkvenih osoba, s obzirom na to da bi se navedeno, u skladu s kanonističkom doktrinom te rimskom pravnom tradicijom iz koje ona dijelom proistječe, moglo podvrgnuti pod pojam otuđenja (alienatio) iz čl. 10. st. 1. Ugovora o pravnim pitanjima.

Zbog toga izgleda kako u pogledu imovine pravnih osoba $\mathrm{KC}$-a de lege lata $\mathrm{i}$ de iure condito što se tiče dobre vjere ili poštenja posjeda postoji stroži režim u odnosu na ostale predmete dosjedanja u domaćem pravnom poretku. Navedeno se može smatrati sasvim opravdanim ako se uzme u obzir kako se na crkvene pravne osobe kad stječu bilo čiju imovinu na isti način primjenjuje jednako strog standard. Osim toga, kako je već istaknuto u literaturi, činjenica je da se inače $u$ pogledu stjecanja imovine crkava i vjerskih zajednica dosjelošću primjenjuju stroži standardi na temelju pradavnog načela koje takvim privilegijem prepoznaje posebnost i važnost njihova poslanja u društvu. ${ }^{78}$ Tako je i hrvatski zakonodavac još prije stupanja na snagu Ugovora o pravnim pitanjima preko $\mathrm{ZV}$-a predvidio dvostruko dulje rokove dosjelosti za stvari u "vlasništvu crkve". ${ }^{79}$

78 Cf. Petrak, op. cit. u bilj. 5 (Codex), str. 701 sq.

79 Cf. čl. 159. st. 4. ZV-a. ZV je stupio na snagu 1. siječnja 1997. (čl. 396.), a Ugovor o pravnim pitanjima, kako je već navedeno ranije, 9. travnja 1997. 
Upravo zbog toga, uza svu ranije navedenu argumentaciju, nije teško zamislivo da je postojala slična logika visokih ugovornih stranaka prilikom koncipiranja čl. 10. Ugovora o pravnim pitanjima.

Inače je kanonsko pravo povijesno gledano već ostvarilo veoma važan utjecaj na svjetovne pravne poretke u pogledu dobre vjere (bona fides) kod dosjelosti. Naime, upravo je ono zaslužno za napuštanje rimske pravne regule mala fides superveniens non nocet te je na temelju njegova moralnog nauka uspostavljeno pravilo po kojemu nije dovoljno da bona fides u bilo kojem obliku postoji isključivo prilikom stjecanja posjeda stvari koja se dosjeda. Izgleda kako je u kontekstu suvremenog hrvatskog pozitivnopravnog okvira suodnos kanonskog i svjetovnog prava u okvirima zajedničke rimske pravne tradicije, barem u jednom dijelu, pošao i korak dalje. Tako je u specifičnim okolnostima i na poseban način nanovo zaživjela izreka čiji je autor poznati kanonist iz 17. st. Anacletus Reiffensteuel: Quando leges non contradicunt canonibus allegantur mixtae ambo. Si quid in altero clarius, valet pro altero. ${ }^{80}$

\section{LITERATURA}

Albisetti, A., Riflessioni sulla bona fides canonistica dopo il Codex del 1983, u: Studi in onore di Gaetano Catalano, vol. I, Rubbettino, Soveria Mannelli, 1998., str. $19-26$.

Apostolova Maršavelski, M., O Gajevu osvrtu na institut usureceptio fiduciae, Zbornik Pravnog fakulteta u Zagrebu, vol. 52, br. 5, 2002., str. 917-932.

Arroba Conde, M. J., Introduzione al diritto canonico, Mondadori, Milano, 2019.

Beal, J. P.; Coriden, J. A.; Green, T. J., New Commentary on the Code of Canon Law, Paulist Press, New York, 2000.

Brasiello, U., Alienatio, u: Azara, A.; Eula, E. (ur.), Novissimo digesto italiano, vol. I/1, UTET, Torino, 1964., str. 480-481.

Brasiello, U., Alienatio, Studia et documenta historiae et iuris, vol. 15, 1949., str. 114-140.

Brkan, J., Crkvena vremenita dobra, Crkva u svijetu, vol. 39, br. 1, 2004., str. 62-94. Brkan, J., Pravne osobe (kan. 113-123), Služba Božja, vol. 34, br. 2, 1994., str. 99-124.

80 U prijevodu: Kada zakoni ne proturječe kanonima, oboje se može uzajamno primjenjivati. Ako je što u jednome jasnije, vrijedi i za ono drugo. ( $c f$. De Paolis, op. cit. u bilj. 2, str. 71, bilj. 72; Orsi, J. C., O princípio de subsidiariedade e a sua aplicabilidade no livro $V$ do Código de direito canônico, Revista de Cultura Teológica, vol. 11, br. 44, 2003., str. 101 - 116, str. 112). 
Brkan, J., Stjecanje vremenitih dobara, Bogoslovska smotra, vol. 74, br. 1, 2004., str. 201-231.

Brkan, J., Ugovori i napose otuđenje, Služba Božja, vol. 45, br. 2, 2004., str. 8-36.

Brkan, J., Zastara u kanonskom i građanskom pravu, Crkva u svijetu, vol. 38, br. 3, 2003, str. 373-390.

Carrière, J., Justitia et jure, Apud Mequignon juniorem, Parisiis, 1839.

Chiappeta, L., Il Codice di diritto canonico. Commento giuridico-pastorale, vol. I, EDB, Bologna, 2011.

Chiappeta, L., Il Codice di diritto canonico. Commento giuridico-pastorale, vol. 2, EDB, Bologna, 2011.

Condorelli, O.; Roumy, F.; Schmoeckel, M. (ur.), Der Einfluss der Kanonistik auf die europäische Rechtskultur, Band 1: Zivil-und Zivilprozessrecht, Böhlau, Köln, 2009.

Daube, D., Mistake of Law in Usucapion, The Cambridge Law Journal, vol. 16, br. 1, 1958., str. 85-92, https://doi.org/10.1017/s0008197300003470.

Dondorp, H., Bona fides praesumitur in classical Canon law, Zeitschrift der Savigny-Stiftung für Rechtsgeschichte, Kanonistische Abteilung, vol. 102, br. 1, 2016., str. 99-122, https://doi.org/10.7767/zrgka-2016-0107.

De Paolis, V., I beni temporali della Chiesa, EDB, Bologna, 2011.

Eterović, N.; Bozanić, J., Ugovori između Svete Stolice i Republike Hrvatske, Glas Koncila, Zagreb, 2001.

Fürst, C. G., Ecclesia vivit lege romana?, Zeitschrift der Savigny-Stiftung für Rechtsgeschichte, Kanonistische Abteilung, vol. 61, br. 1, 1975., str. 17-36, https:// doi.org/10.7767/zrgka.1975.61.1.17.

Gaudemet, J., Il diritto canonico, Giappichelli, Torino, 1991.

Gavella, N., O dosjelosti kao ustanovi našeg pravnog uređenja, Zbornik Pravnog fakulteta u Zagrebu, vol. 26, br. 3, 1976., str. 241-269.

Gavella, N., Posjed stvari i prava, Narodne novine, Zagreb, 1980.

Gavella, N. et al., Stvarno pravo, sv. 1, Narodne novine, Zagreb, 2007.

Guarino, A., Diritto privato romano, Jovene, Napoli, 2001.

Hadžić, A., Dosjelost kao stvarnopravni institut u pravnim porecima kontinentalnoeuropskoga pravnog kruga i pozitivnoj sudskoj praksi, Europski pokret, Grafika, Osijek, Split, 2005.

Hausmaninger, H., Die bona fides des Ersitzungsbesitzers im klassischen römischen Recht, Herold, Wien, 1964.

Hildenbrand, K., Geschichte der Bestimmungen des canonischen Rechtes über die bona fides bei der Ersitzung und Klagverjährung, Archiv für die civilistische Praxis, vol. 36, br. 1, 1853., str. 27-49. 
Iro, G., Sachenrecht, Verlag Österreich, Wien, 2016.

Jacobi Cujacii Opera, tomus sestus, Ex officina frate. Giachetti, Prati, 1838.

Kaser, M., Das römische Privatrecht, vol. 1, C. H. Beck, München, 1971.

Kaser, M., Das römische Privatrecht, vol. 2, C. H. Beck, München, 1975.

Klarić, P.; Vedriš, M., Građansko pravo, Narodne novine, Zagreb, 2006.

Kontrec, D., Stjecanje prava vlasništva dosjelošću na nekretninama u društvenom vlasništvu u svjetlu nove prakse Europskog suda za ljudska prava, Zbornik Pravnog fakulteta Sveučilišta u Rijeci, vol. 38, br. 1, 2017., str. 573-594, https://doi. org/10.30925/zpfsr.38.1.21.

Lumbreras, P., Casus conscientiae antiqui et recentiores, Pontificium Athenaeum "Angelicum", Romae, 1963.

Marthaler, B. L. (ur.), New Catholic Encyclopedia, vol. 3, Gale, Detroit, 2003.

Marthaler, B. L. (ur.), New Catholic Encyclopedia, vol. 12, Gale, Detroit, 2003.

Mayer-Maly, T., Studien zur Frühgeschichte der Usucapio III, Zeitschrift der SavignyStiftung für Rechtsgeschichte, Romanistische Abteilung, vol. 79, br. 1, str. 86-107, https://doi.org/10.7767/zrgra.1962.79.1.86.

Migne, J.-P. (ur.), Theologiae cursus completus, tomus decimus-quintus, Apud editore in Via Gallicè dicta, Parisiis, 1839.

Milaković, G., Dosjelost kao način stjecanja prava vlasništva Republike Hrvatske na poljoprivrednom zemljištu, 1. dio, Informator, vol. 61, br. 6141, str. 5-6.

Milaković, G., Dosjelost kao način stjecanja prava vlasništva Republike Hrvatske na poljoprivrednom zemljištu, 2. dio, Informator, vol. 61, br. 6142, str. 12-13.

Miñambres, J., La remisión de la ley canónica al derecho civil, Ateneo romano della Santa Croce, Roma, 1992.

Musselli, L., Storia del diritto canonico, Giappichelli, Torino, 2007.

Orsi, J. C., O princípio de subsidiariedade e a sua aplicabilidade no livro $V$ do Código de direito canônico, Revista de Cultura Teológica, vol. 11, br. 44, 2003., str. 101-116, https://doi.org/10.19176/rct.v0i44.24972.

Örsy, L. M., Theology and Canon Law, u: Beal, J. P.; Coriden, J. A.; Green, T. J. (ur.), New Commentary on the Code of Canon Law, Paulist, New York, 2000.

Peček, R., Dosjelost u korist nekadašnjeg društvenog vlasništva na nekretnini u privatnom vlasništvu, Informator, vol. 61, br. 6184, str. 5-6.

Petrak, M., Kanonsko pravo i hrvatski pravni sustav (I). Pravni izvori i pravna načela, Zbornik Pravnog fakulteta u Zagrebu, vol. 70, br. 2-3, 2020., str. 251-286, https://doi.org/10.3935/zpfz.70.23.03. 
Petrak, M., Kanonsko pravo i hrvatski pravni sustav (II). Codex Iuris Canonici $i$ suvremeno hrvatsko pravo, Zbornik Pravnog fakulteta u Zagrebu, vol. 70, br. 5, 2020., str. 675-708, https://doi.org/10.3935/zpfz.70.5.04.

Petrak, M., Traditio iuridica: Bona fides praesumitur, Informator, vol. 56, br. 5646, str. 3.

Petrak, M., Traditio iuridica: Quadraginta annorum praescriptio, Informator, vol. 64, br. 6416, str. 3.

Petrak, M., Traditio iuridica: Res habilis, titulus, fides, possessio, tempus, Informator, vol. 64, br. 6425, str. 3.

Petrak, M., Traditio iuridica: Usucapio, Informator, vol. 58, br. 5863, str. 3.

Petrak, M.; Staničić, F., Katolička Crkva, vjerske zajednice i hrvatski pravni sustav, Novi Informator, Zagreb, 2020.

Pranjić, P., Vremenita dobra i vremenita dobra u Crkvi, Katolički bogoslovni fakultet, Sarajevo, Glas Koncila, Zagreb, 2013.

Pugliatti, S., Alienazione, u: Moratti, C.; Pugliatti, S., Enciclopedia del diritto, vol. II, Giuffré, Milano, 1958., str. 1-5.

Robleda, O., El derecho romano en la Iglesia, u: Navarette, U. (ur.), Ius populi Dei. Miscellanea in honorem Raymundi Bidagor, vol. I, Universitá Gregoriana Editrice, Roma, 1971., str. 1-52.

Ruffini, F., La buona fede nella materia di prescrizione. Storia della teoria canonistica, Fratelli Bocca, Torino, 1892.

Scavo Lombardo, L., Buona fede (dir. can.), u: Moratti, C.; Pugliatti, S., Enciclopedia del diritto, vol. V, Giuffré, Milano, 1959., str. 664-677.

Schrage, E. J. H., Res habilis, titulus, fides, possessio, tempus. A medieval mnemonic hexameter?, u: Sturm, F.; Thomas, P.; Otto, J, Liber amicorum Guido Tsuno, Vico Verlag, Frankfurt am Main, 2013., str. 341-355.

Simonetti, P., Stjecanje prava vlasništva primjenom ustanova dosjelosti i uzurpacije na nekretninama koje su bile u društvenom vlasništvu, Zbornik Pravnog fakulteta Sveučilišta u Rijeci, vol. 29, br. 1, 2008., str. 27-70.

Stein, P., Rimsko pravo i Europa, Golden marketing - Tehnička knjiga, Zagreb, 2007.

Škalabrin, N., Stjecanje dobara, Bogoslovska smotra, vol. 75, br. 1, 2004., str. 233-262.

Škalabrin, N., Ugovori i napose otudenje, Bogoslovska smotra, vol. 76, br. 1, 2006. , str. 173-199.

Škalabrin, N., Upravljanje dobrima, Bogoslovska smotra, vol. 75, br. 1, 2005., str. 343-379. 
Škalabrin, N., Uvod u kanonsko pravo, Katolički bogoslovni fakultet Sveučilišta u Zagrebu, Teologija u Đakovu, Sveučilište Josipa Jurja Strossmayera u Osijeku, Pravni fakultet, Đakovo, 1994.

Škalabrin, N., Vremenita crkvena dobra, Bogoslovska smotra, vol. 74, br. 1, 2004., str. 181-199.

Škalabrin, N., Vremenita crkvena dobra, Sveučilište Josipa Jurja Strossmayera u Osijeku, Katolički bogoslovni fakultet u Đakovu, Đakovo, 2008.

Terré, F.; Simler, P., Droit civil: Les biens, Dalloz, Paris, 2014.

Urquiri, T., Cuestiones canónicas aldredor de la buena fe necesaria para la prescripcion, Revista Española de Derecho Canónico, vol. 8, br. 22, 1953., str. 89-119, https://doi.org/10.36576/summa.4116.

Wieling, H. J., Sachenrecht, Bd. 1, Springer, Berlin, 2006.

Zuffellato, A., Il Tractatus de regulis juris di Anacleto Reiffensteuel: spuni critici per una traduzione ragionata (doktorska disertacija), Padova, 2014. (http://paduaresearch.cab.unipd.it/6405/, posljednji pristup 9.12.2020).

Žuvela, M., Dosjelost i društveno vlasništvo, Informator, vol. 56, br. 5707, 2008., str. 1-3.

\section{PROPISI}

Ustav Republike Hrvatske (Narodne novine, br. 56/1990, 135/1997, 08/1998, 113/2000, 124/2000, 28/2001, 41/2001, 55/2001, 76/2010, 85/2010, 05/2014).

Ugovor između Svete Stolice i Republike Hrvatske o dušobrižništvu katoličkih vjernika, pripadnika oružanih snaga i redarstvenih službi Republike Hrvatske. Tekst preuzet iz: Eterović, N.; Bozanić, J., Ugovori između Svete Stolice i Republike Hrvatske, Glas Koncila, Zagreb, 2001. (vidi i Odluku o proglašenju Zakona o potvrđivanju tog ugovora, Narodne novine, Međunarodni ugovori, br. 2/1997).

Ugovor između Svete Stolice i Republike Hrvatske o gospodarskim pitanjima. Tekst preuzet iz: Eterović, N.; Bozanić, J., Ugovori između Svete Stolice i Republike Hrvatske, Glas Koncila, Zagreb, 2001. (vidi i Odluku o proglašenju Zakon o potvrđivanju tog ugovora, Narodne novine, Međunarodni ugovori, br. 18/1998).

Ugovor između Svete Stolice i Republike Hrvatske o pravnim pitanjima. Tekst preuzet iz: Eterović, N.; Bozanić, J., Ugovori između Svete Stolice i Republike Hrvatske, Glas Koncila, Zagreb, 2001. (vidi i Odluku o proglašenju Zakona o potvrđivanju tog ugovora, Narodne novine, Međunarodni ugovori, br. 3/1997). 
Ugovor između Svete Stolice i Republike Hrvatske o suradnji na području odgoja i kulture. Tekst preuzet iz: Eterović, N.; Bozanić, J., Ugovori između Svete Stolice i Republike Hrvatske, Glas Koncila, Zagreb, 2001. (vidi i Odluku o proglašenju Zakona o potvrđivanju tog ugovora, Narodne novine, Međunarodni ugovori, br. 2/1997).

Zakon o obveznim odnosima, Narodne novine, br. 35/2005, 41/2008, 125/2011, 78/2015, 29/2018.

Zakon o vlasništvu i drugim stvarnim pravima, Narodne novine, br. 91/1996, 68/1998, 137/1999, 22/2000, 73/2000, 129/2000, 114/2001, 79/2006, 141/2006, 146/2008, 38/2009, 153/2009, 143/2012, 152/2014.

Codex Canonum Ecclesiarum Orientalium fontium annotatione auctus (Zakonik kanona istočnih Crkava s izvorima), Glas Koncila, Zagreb, 1996.

Codex Iuris Canonici fontium annotatine auctus (Zakonik kanonskog prava s izvorima), Glas Koncila, Zagreb, 1996.

Codex Iuris Canonici fontium annotatione auctus MDCCCCXVII (Kodeks kanonskog prava s izvorima 1917.), Glas Koncila, Zagreb, 2007. 
Summary

\section{Henrik-Riko Held*}

\section{BONA FIDES (GOOD FAITH) IN PRAESCRIPTIO ACQUISITIVA AND ADVERSE POSSESSION - A CONTRIBUTION TO THE DISCOURSE ON THE INTERRELATIONSHIP BETWEEN CANON LAW AND CROATIAN LAW}

The author analyses bona fides, or possession in good faith, as a prerequisite of the canonical praescriptio acquisitiva and the adverse possession as set forth in contemporary Croatian law in their interrelationship. The problem stems from the fact that the Treaty between the Holy See and the Republic of Croatia on legal matters, being an international treaty and thus having precedence over Croatian laws according to the Croatian constitution, in certain circumstances allows for a direct application of canon law within the Croatian legal system. The aim of this paper is to analyse whether this also applies to bona fides in adverse possession, and if so, in which way exactly. The canonical praescriptio in the context of the Roman legal tradition is analysed first in order to clarify certain terminological and conceptual discrepancies between canon law and Croatian law in this field. Bona fides regarding usucapio and praescriptio of Roman law and the Roman legal tradition is then particularly addressed. The central part of the paper deals with canonical bona fides, where it is specifically noted that it is a stricter standard in comparison to good faith as found in Croatian law. Canon law requires positive good faith throughout the whole required prescription period, meaning knowledge or a reasonable possibility of knowledge of having a right to possess, not infringing the right of another thereby. On the other hand, Croatian law requires knowledge or possibility of knowledge at the outset, while later on only acquired knowledge will render possession illicit. In addition, the Croatian standard of good faith is conceived more simply in comparison to the twofold canonical standard, i.e. only as the absence of knowledge or possibility of knowledge of not having a right to possess. Although both systems presume good faith, those differences may prove crucial if an interested party (owner of property being prescribed) offers evidence to the contrary. Finally, our analysis of the Treaty between the Holy See and the Republic of Croatia on legal matters revealed that the canonical standard of bona fides should be applied whenever a juridical person of the Catholic Church in Croatia acquires property by means of adverse possession, but by all accounts also when any other person acquires Church property in the same way.

Keywords: bona fides, good faith, praescriptio, adverse possession, canon law

* Henrik-Riko Held, Ph. D., Assistant Professor, Faculty of Law, University of Zagreb, Trg Republike Hrvatske 14, 10000 Zagreb, Croatia; hheld@pravo.hr;

ORCID ID: orcid.org/0000-0002-6217-2655 